Schmidt M. (2008): Land use, land administration and land rights in Shigar,

Baltistan. In: van Beek M., Pirie F. (Hg.): Modern Ladakh. Anthropological

Perspectives on Contiuity and Change. Brill's Tibeatan Studies Library Volume

20, Leiden: Brill, 243-265.

\title{
Land use, land administration and land rights in Shigar, Baltistan
}

\author{
Matthias Schmidt
}

Shigar, located in the central Karakorum, is one of the main valleys in Baltistan. Traditionally, mixed mountain agriculture, a combination of animal husbandry and crop farming based on canal irrigation, forms the main element of the subsistence economy of almost all households in Shigar. Apart from water, which is essential in this arid region, land can be seen as the fundamental resource for economic activities. Consequently, the entitlement to dispose of land has always been linked with social status and political influence. It will be shown how land administration, revenue systems and property rights have changed over the past two centuries. An understanding of land use and property rights also offers a deep insight into the socio-political and economic system of Shigar.

\section{Introduction}

High peaks, masses of rocks and extensive glaciers, on the one hand, and densely populated valleys with flourishing village oases, on the other, are probably one of the most apparent characteristics of Baltistan in the Central Karakorum. There is a stark contrast between irrigated agricultural land in the valleys - intense green spots in summer - which accounts for not more than $5 \%$ of the land cover, and the vast unpopulated and hostile high mountain terrain. The visitor wonders how people can sustain a living in such a desert-like environment, and is impressed by the achievements of the local population, which has created village oases with elaborate forms of land and water utilisation. One goal of my research in Shigar is to gain an understanding of indigenous concepts of land use and land management, and how these concepts have been transformed over time by outside influences. Land resources with limited agricultural potential, such as semi-deserts and high mountain areas - in Shigar we find a combination of both - are often defined as 'commons' or 'common property' resources on which specified user groups hold usufruct rights (Hardin, 1968; Berkes, 1989; Ostrom, 1990; Feeny et al., 1990; Singh, 1994; Baker, 1997; Berkes et al., 1998; Ostrom et al., 2002; Schmidt, 2004a). While the more valuable irrigated lands in the valleys are mainly used and managed by smaller economic units, typically the household, and held as private property, the complex irrigation systems are the result of collective action and are generally overseen in a collective way. This leads to questions about the success, effectiveness and sustainability of past and present forms of land use and land management, in which rights of access, possession, and ownership, as well as the role of autochthonous institutions, play a significant role. ${ }^{1}$

\footnotetext{
${ }^{1}$ Empirical fieldwork in Baltistan was carried out between 1996 and 1998. Within the empirical data collection, qualitative, reconstructive forms of empirical social research were preferred, including participatory observation and focused interviews. Semi-standardised interviews were conducted in all villages within the research area, and thematically focused interviews with local experts served to obtain more in-depth information about specific aspects. Rare monographs, documents and written material were analysed at the
} 


\section{Utilisation of land resources for agriculture and animal husbandry}

Geographically, Shigar is located in the Central Karakorum, north of Skardu, the capital of the historically and linguistically distinct region of Baltistan. Shigar, as a political unit, comprises the valleys of the Shigar, Basha and Braldo rivers, as can be seen in Fig. $1 .^{2}$ Its settlements are located only in the valleys, on alluvial fans, gentle slopes or terraces above the rivers, at altitudes between $2300 \mathrm{~m}$ (Marapi) and $3050 \mathrm{~m}$ (Askole). ${ }^{3}$

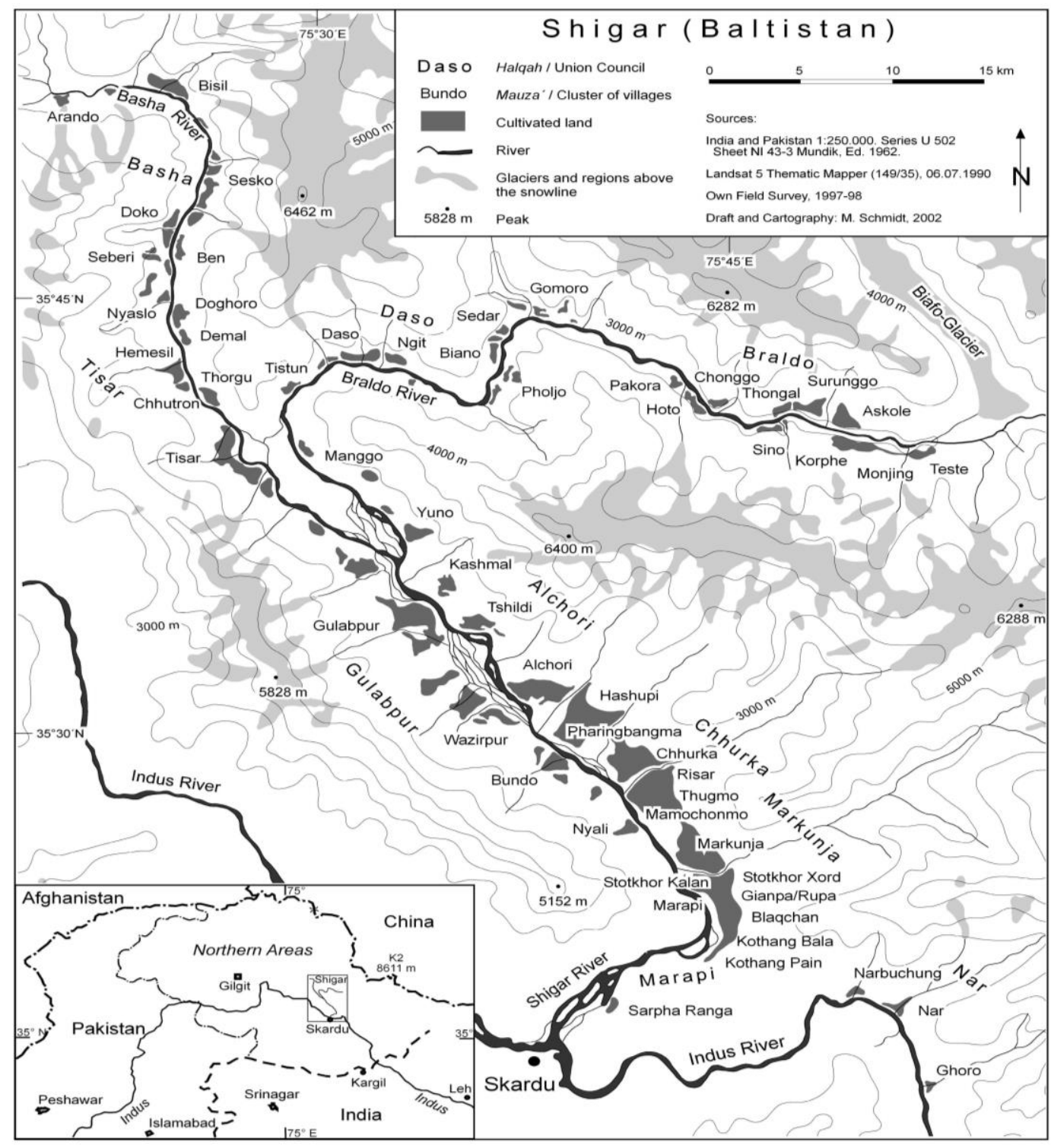

Figure 1: The valleys of Shigar, Basha and Braldo.

In an environment with limited agricultural resources, the population of Shigar needs to utilise different ecological niches to sustain its livelihood. Mixed mountain agriculture (Rhoades and Thompson, 1975), a

India Office Library \& Records during a two-month stay in London. Colonial cadastres produced for every village during the land settlements at the beginning of the $20^{\text {th }}$ century, with information on land possession, land revenues, and on water and pasture rights were appraised at local and regional offices in Baltistan.

${ }^{2}$ Below, when Shigar is mentioned, the reference is to the whole region, including the Shigar, Basha and Braldo valleys.

${ }^{3}$ Detailed papers on Shigar are given by Hewitt (1991), MacDonald (1994) and Schmidt (2004b). 
combination of crop farming and animal husbandry, forms the basis of the subsistence economy of the local population, whereby the two elements not only complement but also depend on each other (Ehlers and Kreutzmann, 2000). In the valleys, with their arid to semi-arid conditions, the local population of Shigar have established complex irrigation systems and arable lands in a long process of canal construction, ground levelling and amelioration. Gentle slopes and fans provide the ground for crops, fruit and vegetable gardens and meadows. The non-irrigated surroundings are not just unused wasteland; they also function as pasture land, though the areas vary significantly in their fodder value. The lower parts of the steep slopes that surround the rivers of Shigar feature only a meagre vegetation of Artemisia (burse $)^{4}$ and are often simply too steep and, thus, less favourable for pasture, while a belt of relatively dense grassy vegetation at altitudes between 3500 and 5000 $\mathrm{m}$ serves as alpine pasture for livestock during the summer months. ${ }^{5}$

As regards irrigated crop farming, the most important crops in Shigar are wheat (tro) and barley (nas), grown in several different local and adopted varieties. According to statements from local farmers, the amount of barley cultivation has decreased over the past few decades in favour of wheat. The vegetation period in the areas lower than $2600 \mathrm{~m}$, that is, the lower Shigar valley, allows the cultivation of two crops per season when barley is sown as the first crop, which is harvested in early July, while in all other higher elevated areas only one crop per year can reach maturity. Usually buckwheat (blo) and millet (tsetse, chha) are sown as autumn crops. The latter is only used as a fodder crop and is generally harvested before reaching maturity. However, it is not only climatic factors that inhibit the cultivation of autumn crops but more often social aspects. Autumn crops will fail, for instance, if communal decisions do not guarantee that livestock is banished from the field area during the ripening period ending in October. In other words, the individual decision of a farmer to cultivate a second crop is dependent on collective actions. Other crops cultivated in larger amounts only in Basha and Braldo are beans (mothu, naqstran) and peas (boqstran). Formerly only planted in small amounts in kitchen gardens, potatoes (alu) have recently become important cash crops in the valley - a tendency that can be found in other parts of Northern Pakistan as well (Kreutzmann, 1993:37). ${ }^{6}$ The different cropping patterns of the double and single cropping zone can be seen in Fig. 2 and 3.

\footnotetext{
${ }^{4}$ Words in italics are transliterations of commonly used local terms either of the Tibetan dialect Balti or, in connection with land administration, of Pakistan's lingua franca Urdu.

${ }^{5}$ Non-agricultural activities such as trade, crafts and labour migration, that always played an important part in balancing the deficits of the subsistence economy, are not discussed here because of their lesser relevance regarding the management of land. For details about these aspects see Schmidt (2004b).

${ }^{6}$ The advantages of growing potatoes in the mountainous region of Northern Pakistan are favourable climatic conditions for the crop and a harvest time which differs from those in the lowlands of the Punjab, the main destination for the potatoes.
} 


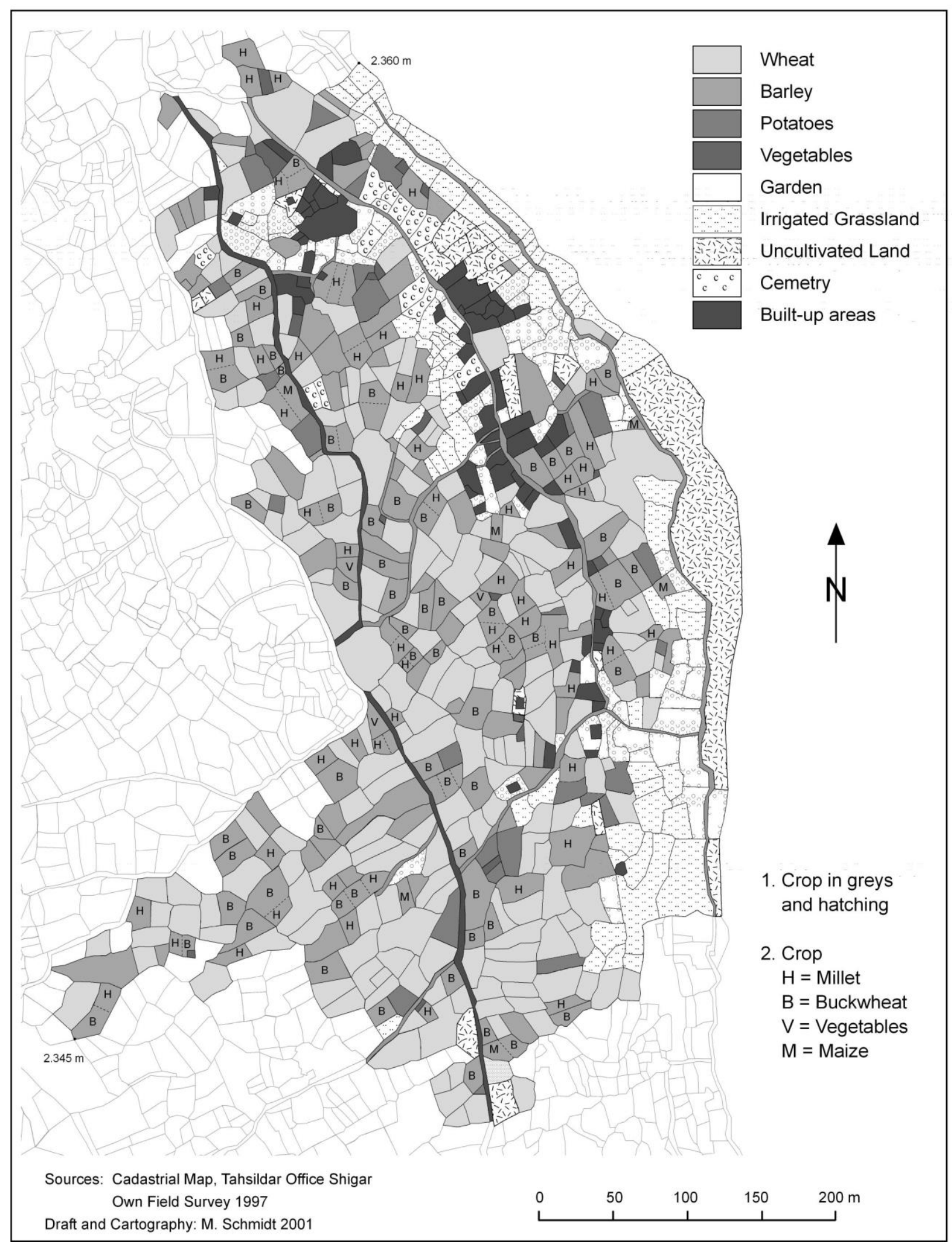

Figure 2. Land use in Balqchan (Union Council Marapi). 


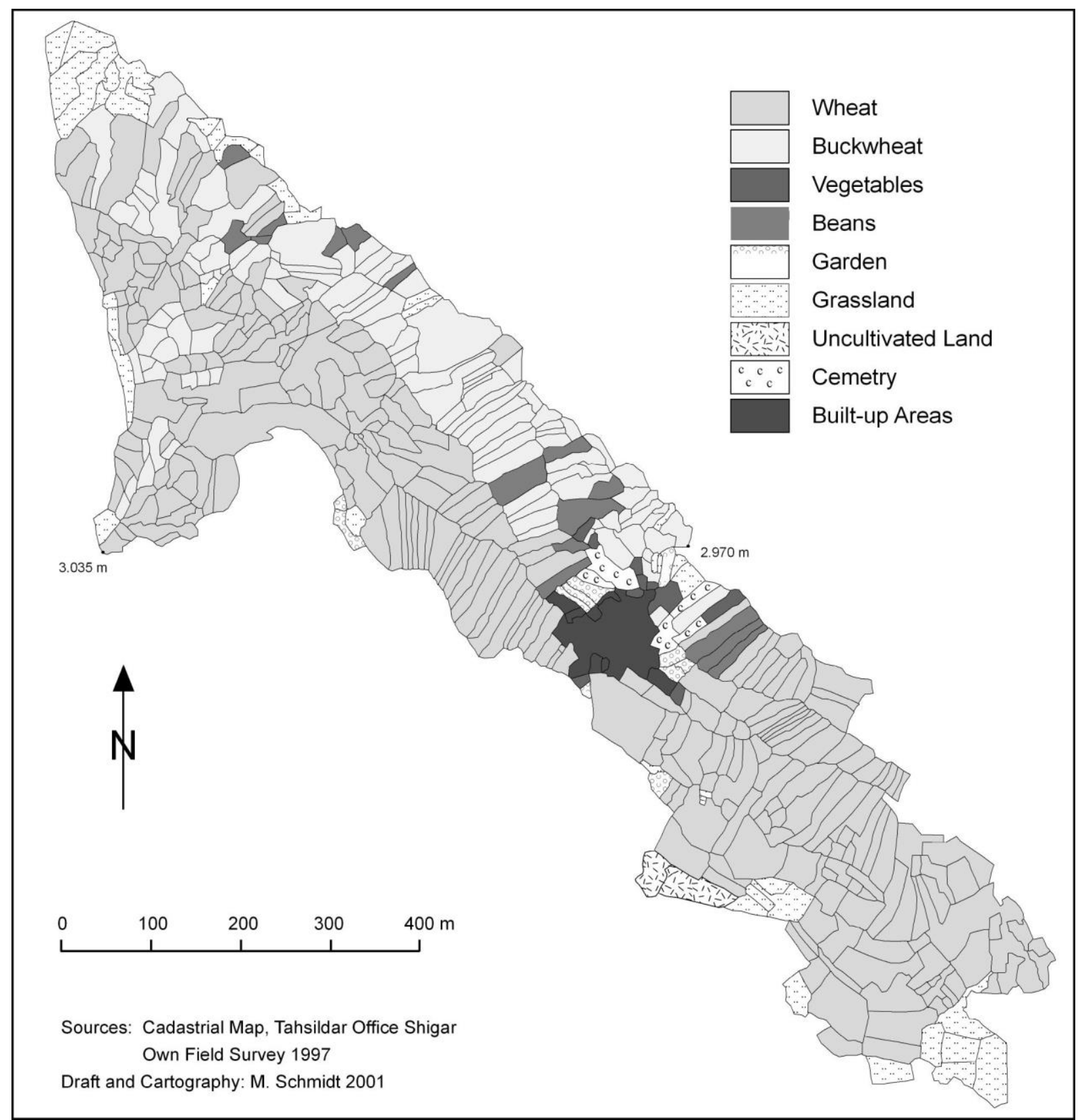

Figure 3. Land use in Hoto (Union Council Braldo).

Different kinds of vegetables like spinach (palak), cabbage (karam), salad (salad), turnips (mulo), onions (tsong), pumpkins (wan) and tomatoes (paghan) are grown mainly in kitchen gardens (drumba) or on small parcels at the edge of arable fields near the villages. It is remarkable that almost no fields in Shigar are sown with specific forage crops like alfalfa or rape. This fact can be interpreted as an indication of the limited availability of ground, which seems to be too valuable for the cultivation of forage. For the necessary stall feeding from late autumn until early spring, grass is cut on irrigated meadows $(o l)$, which are located at the periphery of the field area, mostly in less favourable locations, such as on slopes. The small grassy strips along canals and paths as well as the numerous fruit gardens (tshar) are also mowed regularly. Apricots (chuli), the most important tree crop in Baltistan, are grown in at least 15 different varieties in Shigar. Other typical local fruits include mulberries (ose), walnuts (starga), apples (kushu) and grapes (rgun). Until the partition of India, dried apricots (pharing) and apricot kernels played an important role as barter goods, being exchanged for other products like salt, pots, and pashmina from neighbouring areas, especially Ladakh (Grist, 1985:92; Afridi, 1988:289; Sheikh, 1998:342; Rizvi, 1999:32). Finally, 
non-fruit trees - poplars (ghbyarpha), Russian olives (sarsing) and willows (hlchaxma) - not only deliver timber and firewood, but also leaves for fodder.

Animal husbandry, the other pillar of mixed mountain agriculture, involves livestock being kept in villages from autumn to late spring and taken up to alpine pastures in summer. The livestock comprises yak (hyaq, hyaqmo), zo and zomo (a cross-breed of yak and cow), cows (ba), bulls (xlang), goats (rabaq) and sheep (lu) (Schmidt, 2000). Yaks are kept only for breeding purposes, in order to produce the highly valued zo and zomo, but are not used for traction power or as pack animals, as is the case in some regions of Ladakh (Mann, 1986:106; Osmaston et al., 1994:201). In contrast to other livestock, in the lower Shigar valley yaks are not kept by individual households but by village communities. Normally only one yak is bought and kept by a village community or neighbourhood, while the number of yaks is significantly higher in Basha and Braldo, with their extended pasture lands, where several households keep yaks and sell them to village communities from lower Shigar. Zo and bulls have been, and in some villages are still, used for ploughing and threshing purposes, but since there are more and more tractors and threshing machines available in the valley the importance of keeping zo and bulls is declining. The infertile zo are mostly slaughtered before reaching maturity. Zomo and cows are the main milk animals, goats are also kept for their milk, skin and meat and sheep for their wool and meat. A small number of donkeys (bongbu) are used as pack animals, while today not more than 20 horses ( $h r t a$, rgunma) are kept in the whole area for the purpose of playing polo. Additionally, the dung of all animals is highly valued as fertiliser for the fields and the animals, themselves, are an important investment which can be transferred into cash in cases of emergency. Generally, one finds relatively large herds in the villages of Basha and Braldo, with an average of 12 to 15 bovines and 20 to 30 head of sheep or goats per household, while significantly smaller herds, 5 to 7 bovines and 10 to 15 sheep or goats, kept by the farmers of the lower Shigar valley, reflecting the size of their pasture areas. As already mentioned, the people utilise various pasture resources at different altitudes by means of ingenious mobility patterns. Only the rich alpine pastures provide enough fodder for all livestock and they can only be used in the summer months. During the rest of the year the animals are dependent on the meagre pastures in the valleys and on the lower parts of the mountain slopes, as well as on forage gained from agricultural land. Crop residues, tree leaves and hay serve as fodder from autumn until spring. Therefore, the most important restricting factor for the size of a herd is the amount of fodder that can be supplied for the livestock during the winter months.

Tab. 1 Population of Shigar between 1911 and 1998

\begin{tabular}{|lllllll|}
\hline Union Council & $1911^{\mathrm{a}}$ & $1951^{\mathrm{b}}$ & $1961^{\mathrm{c}}$ & $1972^{\mathrm{d}}$ & $1981^{\mathrm{e}}$ & $1^{\mathrm{a}}$ \\
\hline Total & 26,256 & 24,136 & 24,723 & 27,738 & 32,364 & 45,322 \\
\hline
\end{tabular}

Sources: Dainelli (1924:392); Afridi (1988:271-274); Malik (1961:3-5); Government of Pakistan (1972:46-49; 1984:48-50; 2000:2254-2257). All numbers are based on census data.

As shown in this chapter, there is an interdependence and reciprocity between arable farming, the cultivation of fruit and vegetable gardens, grass cropping and animal husbandry. The diversity of crops and animals can be seen as a strategy for securing a livelihood which not only helps to extend the food base but also results in a diversification of risks and, therefore, a reduction in vulnerability. For centuries, the agrarian utilisation of land in the form of the mixed mountain agriculture was the main economic occupation which sustained the livelihood of the local population. However, due to a tremendous population growth over the last century (Table 1), the use of land for agriculture could no longer guarantee the livelihood of Shigar's population. Topographical and ecological conditions, as well as a lack of financial means, restrict the potential for new land colonisation. Thus 
non-agricultural incomes are playing an increasingly important role in household strategies. Forms of nonagricultural employment practised in recent decades include labour migration - seasonal to Skardu and Gilgit, temporarily to big cities in Pakistan or to the Gulf States - employment by the government or the army and working as porters for the numerous mountain expeditions and trekking groups. Yet agriculture and animal husbandry still fulfil their function as the primary pillar of households' survival strategies.

\section{The land administration and revenue system in historical perspective}

Land as political territory, has always been a source of power or, to put it the other way round, political power has generally been linked to holding sway over a specific territory. To retain power, rulers not only had to defend their territory against enemies from outside, they also needed to control their own populations, which meant raising funds to support a military force. In Baltistan, where cultivated land is a scarce, but fundamental, resource in the subsistence economy, agricultural, and to some extent pastoral, lands were always at the centre of the revenue systems.

\section{Revenue system before land settlement}

Until the middle of the $19^{\text {th }}$ century, Shigar was ruled by local autocratic sovereigns (cho) (Schuler, 1978; Emerson, 1984; Hashmatullah Khan, 1987), whose authority was grounded on a system of land revenues and dues. All land within the political boundaries of Shigar was defined as the property of the ruling cho, who allowed it to be cultivated by local farmers only in exchange for services (res) and revenues, which had to be paid in kind in the form of grain, livestock, butter, apricot nuts, wool, grass or wood. ${ }^{7}$ Nevertheless, according to Hashmatullah Khan (1987:136f.), only soldiers or persons who enjoyed the favour of the cho might be given land as a gift and thus acquire the status of land proprietors. However, the cho could take such land back at will.

In 1841, the Dogras conquered Baltistan, established a garrison and an administration in Skardu headed by a thanadar and subsequently ruled an area which included Shigar. Haider Khan, the former cho of Shigar and leader of an unsuccessful revolt against the Dogras, was imprisoned in Srinagar and replaced by a relative who was a puppet ruler for the Dogras. When, in 1846, the British signed the treaty of Amritsar and made Gulab Singh the maharaja of Jammu and Kashmir, Baltistan became part of the Princely State of Jammu and Kashmir. The maharaja declared that as he had purchased the valley of Kashmir from the British he was the sole owner of all lands in his territory and farmers were only his tenants-at-will (Thorp, 1870:26). However, at the regional and local levels, the cho of Shigar retained - at least for some decades - his right to collect revenues and to organise the administration, but the civil servants of the maharaja demanded tribute from him to finance their garrison and administration in Skardu. The authority of the cho was gradually undermined and after some decades land revenues were collected by the administration of Jammu and Kashmir State, itself. A further nominal change occurred in 1899 when a Frontier District comprising Ladakh, Baltistan and Gilgit was formed. Two years later, in 1901, a newly established Skardo Tahsil became part of the Wazarat of Ladakh.

To sum up, prior to the appropriation of property rights by the maharaja, although the cho nominally owned all land, the local farmers acted de facto as landowners with inheritable property rights, a situation that was overturned by the new regime implemented by the government of Jammu and Kashmir. A land possessor was regarded by the State administration as a tenant-at-will, whose usage rights over land were dependent on the

\footnotetext{
${ }^{7}$ In contrast to the revenue collection per house or hearth, as practised in Ladakh (Cunningham, 1854:268f.; Imperial Gazetteer of India, 1908:101; Petech, 1977:158), revenues in Baltistan had to be paid according to land size, measured in ghund and yol (Vigne, 1842:258; 397).
} 
will of the owner - the state. However, it is not so easy to evaluate to what extent actual control over agricultural land at local levels changed over the years and who actually made decisions about land cultivation and land inheritance.

\section{Land settlement (bandobast): measures and effects}

Under British assistance a land settlement was carried out in Jammu and Kashmir originally in the Valley of Kashmir under the supervision of settlement officer Walter Lawrence. This is said to be one of the most important reforms undertaken during the existence of this Princely State (Lawrence, 1895; Imperial Gazetteer of India, 1908). Skardo Tahsil of the Wazarat of Ladakh was settled for the first time in 1901 by Settlement Officer Clarke and a second time in 1911 under the supervision of Thanadar Singh. Means and measures of land settlements included a land survey resulting in different maps drawn on cloth, the definition of occupancy and property rights for land, a revenue assessment based on land cultivation and average yields, the laying down of pastoral rights for each village and the reorganisation of administration (Singh, 1914; Afridi, 1988:238ff.).

With regard to Shigar, the land settlement had the following effects:

a) Reorganisation of administration: the head of the revenue administration within the tahsil became the tahsildar (district governor), followed by several naib-tahsildars. Shigar, including Basha and Braldo, formed a so-called girdawar halqa within Skardo Tahsil. Administratively, it comprised ten halqa (circles) and 57 mauza. ${ }^{8}$ The girdawar controlled ten patwari, each of the latter being responsible for revenue collection and updating the settlement records in one halqa. In the first decades of the $20^{\text {th }}$ century the revenue officers were mainly Kashmiri and only after the first schools were opened in Baltistan did local Balti obtain some minor posts within the revenue administration. Apart from that, one man from each mauza was nominated as the nambardar, so that Balti people were involved in the revenue administration at local levels. The nambardar was accountable for tax collection in his mauza and received as a wage five per cent of the revenues exacted. Furthermore, he was responsible for certain communal affairs such as the settling of disputes or the organisation of res. ${ }^{9}$

b) Definition of occupancy and property rights: although the maharaja of Jammu and Kashmir declared all land within his territory to be his own, with the settlement local villagers were given different occupancy rights, which were noted in the records by name and field - for the first time ever in Shigar. A differentiation was made between three types of land possessors or occupants: the Haq-i-asami had the right of possession as long as dues were paid, but he was not allowed to alienate the land. The utilisation right of the tenant-atwill was dependent on the will of the land proprietor and could be changed or cancelled at any time. In the case of the occupancy tenant, right of possession was protected, lease of land was fixed and his occupancy right was inheritable. ${ }^{10}$ Aside from that, the former cho of Shigar was given rights as a jagirdar (big land owner), which meant that he could keep his landed property and the right to collect leases from such land (jagir).

\footnotetext{
${ }^{8}$ A mauza is an administrative unit consisting of one or several villages or hamlets (drong).

${ }^{9}$ Res was a system by which a village or group of villages was bound to supply transport and food for certain stages on certain roads (Afridi, 1988:249; Sheikh, 1998:341). Literally res stands for turn system with regard, for example, to herding practices, communal work on canals or water rights. Sometimes res is used synonymously with begar to refer to forced labour. The concept of res is also known and applied in Ladakh (Cunningham, 1854:269; Imperial Gazetteer of India, 1908:100).

${ }^{10}$ It was not until 1933 that property rights were granted and most land users became land proprietors (Lentz, 2000).
} 
c) Land classification and soil categories as a basis for revenue assessment: as an important step for laying down a uniform, objective and controllable basis for revenue assessment, land was classified according to its usage and value. Only land within the so-called settled areas was assessed. Settled areas included villages with their irrigated surroundings, while all other lands like mountains, glaciers, pastures and other waste land fell into the category of unsettled areas. Within the settled areas land was divided into cultivable land (banjerkadim) and non-cultivable land (ghermumkin), such as canals, paths and rocks. In Shigar the cultivable land was used as gardens for fruit and other trees, vegetable or kitchen gardens, meadows and crop land, the latter was further specified according to its quality as maljing (best agricultural land), bartshot (good agricultural land), and das (less favourable agricultural land). ${ }^{11}$ However, for the amount of revenues that had to be paid by the cultivators not only size and defined type of soil were relevant but also the regional location. Villages, or rather their agricultural lands, were ranked into four classes according to climatic factors (altitude and exposition), types of crops that could be grown, possibility for double cropping and growing fruit. According to this list, the agricultural land of the villages in the lower Shigar Valley, where two crops per season could be achieved and a variety of fruits and crops were cultivated, was classified as the best, while the land in the upper Braldo was ranked as the worst, due to the unfavourable climatic conditions at $3000 \mathrm{~m}$ (Singh, 1914:7ff.). Fig. 4 shows the different types of land as classified by the settlement.

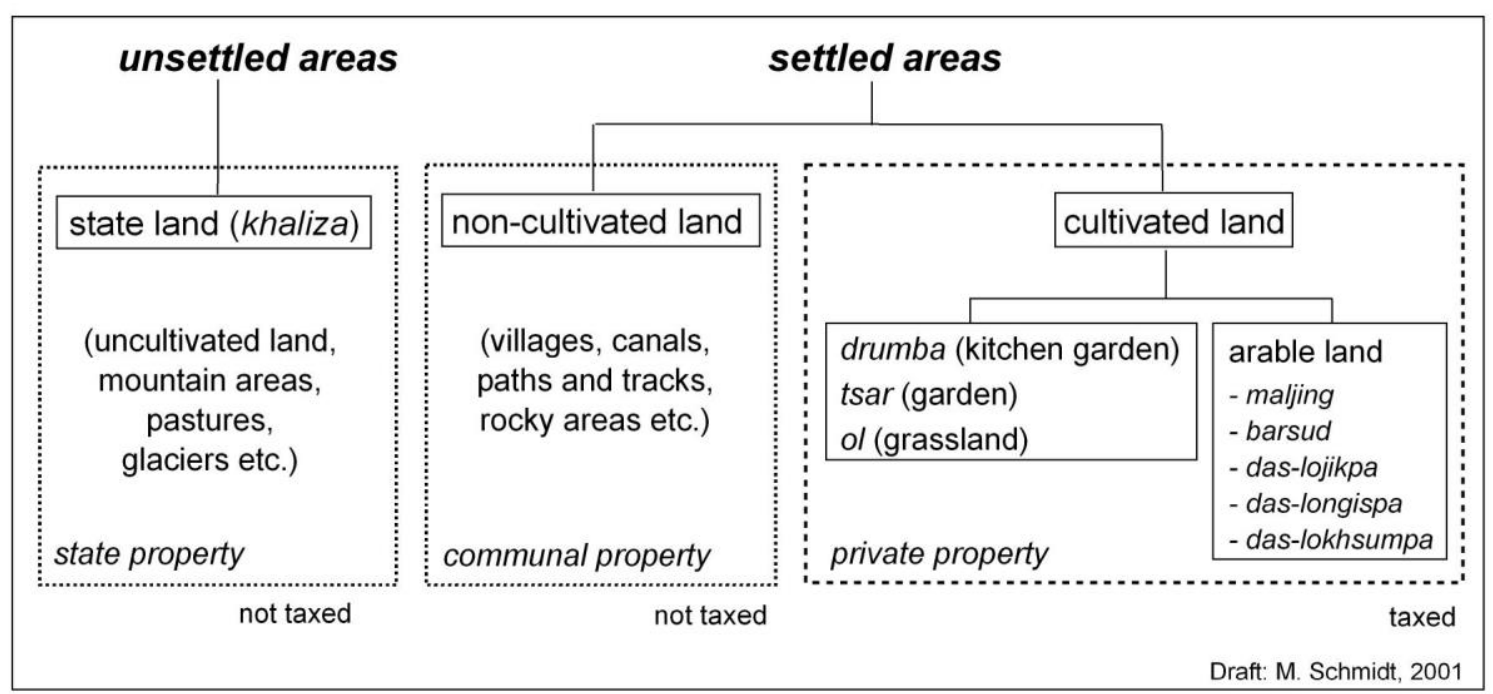

Figure 4. Land classification according to revenue records.

d) Fixing land revenues: in accordance with the aforementioned differentiation of land classes, taxes for a specific field had to be paid according to location (village category), size, land usage and soil quality. Revenues were fixed for 14 years in the records for each field and each land proprietor and had to be paid in cash, with additional payments being made in kind, mainly grain. The payable wheat and barley had to be brought by each farmer to the governmental grain depots (kothi) and was used for the alimentation of the administration and garrison or sold on the market.

\footnotetext{
${ }^{11}$ It is remarkable that the terms used in the revenue records for the type of land utilisation and soil quality are of the vernacular Balti, which is a hint that the classification reflects autochthonous concepts of soil evaluation and land utilisation. Fields were classified roughly according to their distance from the villages: the nearer the fields to the built-up areas the better the soil quality.
} 
All the results of the settlement were written down in the revenue or settlement records, which were composed of different registers (Misal-i-haqqiyat, Khasra-Girdawari, Register Intequalat, Dalbatch) and maps (masawi, lata). Land utilisation and crops grown on each field were inspected annually for the levy of revenues, an inspection that was called girdawari.

When looking at the results and effects of settlement one has to distinguish between the different groups involved. For the government, and especially the maharaja, the settlement without doubt increased the state income (Imperial Gazetteer of India, 1908:77; Younghusband, 1909:187). But for the tax-payers, the pressure to pay taxes was very high and tax exemptions or reductions for poor households were not approved. A significant number of farmers had to sell part of their land or livestock because they were unable to pay their taxes. As a result many young Balti left the Princely State of Jammu and Kashmir to avoid the hardship of taxation and emigrated to other parts of British India. ${ }^{12}$

\section{Land administration after 1948 and the revitalisation of autochthonous institutions}

Immediately after independence in 1948, the first war was fought between India and Pakistan, resulting in the dissection of the former principality of Jammu and Kashmir by a still disputed and hard-fought cease-fire line. Baltistan, together with the former Gilgit Agency, came under the administration of Pakistan as disputed territory without achieving the status of a full province. Traditional links to Ladakh and to the valley of Kashmir were cut by the cease-fire line. Consequently, the direction and partners for commercial and political relations had to be modified. New roads had to be constructed linking Baltistan with the rest of Pakistan, first via the Deosai Plateau and, since 1968, via the Indus valley.

In the first decades after independence, Baltistan became an Agency, with Skardu as its capital. Union Councils were established at local levels, but the revenue system persisted. Important reforms were carried out only during the government of Zulfikar Bhutto between 1972 and 1974: Baltistan was made a District within the Northern Areas and Shigar became a sub-division with its own Assistant Commissioner. The begar, res and jagir systems, along with the collection of all land taxes were abolished and land possessors - apart from tenants became real land proprietors. As a result, the post of nambardar for each mauza was no longer needed and was, thus, abandoned, with the effect that local institutions like the village elders (tsharma) were revived. On the other hand, the regulations that were fixed during the settlement for pastures and irrigation systems have remained in force and are still followed by the users. Land ownership and land transactions are still recorded by the patwari in the revenue records, but since there is no longer any need to do so for tax collection purposes, nowadays the settlement records are in a very bad condition and are only partly up to date.

It is interesting to note how autochthonous institutions have persisted or been transformed by the different historical events. The village elders or headmen (tsharma) play an important role in communal affairs today. They settle disputes, determine the date for sending the animals to alpine pastures and fix the day of canal cleaning. Furthermore, the tsharma nominate canal watchmen (hrkongstrung) and sometimes organise the distribution of an estate among heirs. Conflicts about authority and competence occurred in some villages between former nambardar and the present tsharma, although it is not uncommon that the former nambardar became the tsharma of one village. The assertiveness and power of tsharma vary from village to village and depend on charisma, personal authority and competence. It seems that the authority of the tsharma is higher in

\footnotetext{
${ }^{12}$ Other reasons for emigration included kar-i-begar, an onerous form of forced labour. Besides this, young men were forced to work as porters ("coolies"), not only in Baltistan but also in the whole state of Jammu and Kashmir (Knight, 1893:66ff.; Lawrence, 1895:411ff.; Robertson, 1896:337; Younghusband, 1909:231ff.).
} 
villages at the periphery than in villages near the centre, probably due to their remoteness and, thus, the weaker presence of the governmental administration representatives.

\section{Property and utilisation rights over land}

\section{Land as a common property resource}

With regard to land rights in Shigar, one must recognise the existence of two main types of land resources primarily defined by their user groups. Irrigated agricultural lands, such as fields, gardens and meadows, are possessed and used by individuals or small groups of individuals like households or families, and correspond to the settled areas. Though they are used by individuals as well, the utilisation rights for all other lands outside the village "oases", the unsettled areas, are either not defined, which is the case for the majority of mountain terrain - rocks, glaciers and steep slopes, or they are in the hands of user groups such as village communities. The latter is true of the majority of the best pasturelands.

Due to the relatively small fodder base in Shigar, all reachable lands that are at least sparsely covered by grasses or bushes are potential pastures. Locals divide them into bloq or lungma, which refers to the alpine pastures located at altitudes between 3500 and 5000 m, ranga, which covers the desert-like slopes near the villages and the periodically flooded alluvial land near the river, and $o l$, the irrigated meadows. All pastures apart from the privately held ol are per definition, legally government land (khalisa) and, thus, accessible for everybody. However, for the most valuable pastures, in particular the alpine pastures, access and utilisation is limited to well-defined user groups. Such specified pasture rights were written down for each mauza during the settlement and are still in force. ${ }^{13}$ Most likely they are based on local customs and are not an invention by the settlement administration, as locals have made statements about the form of pasture use practised before such customs were put into force by the settlement administration. In most cases, usufruct rights over pastures are related to the village communities of a specific settlement, mostly the nearest one, and are always linked with duties, such as the repair of paths and pasture huts.

Thus, pastures are commons, used and possessed by a specified user group, while the pasture land is, and has always been, legally owned by the central authority, be it the cho, the maharaja of Jammu and Kashmir or the government of Pakistan. Although conflicts over the usufruct rights of pastures occasionally occur, mainly between different village communities, the present compromise between legal and governmental ownership and common possession seems to work. It does so, at least, under the present conditions in which pasture land has a relatively low value. The state does not normally interfere in communal affairs. This situation could, however, become precarious if the owners' interest in land increased due to the identification of valuable resources in the area, such as minerals or wood, or due to other forms of land use, such as for the construction of roads or governmental buildings, or establishing camp sites for trekking tourists. In such cases the government could insist on its ownership right and could exclude traditional user groups from the land.

\section{Land as a private property resource}

Individually used or privately possessed lands include agricultural fields, gardens and meadows. All such plots are registered in the revenue records which also include information about size, usage and proprietor. Fields are

\footnotetext{
${ }^{13}$ Pasture rights are laid down for each mauza in a document called naql-kahcharai, while other land use rights regarding tree planting, the paying of craftsmen, rights to minerals, wood etc. are specified in the document wajibul-arz ("what else has to be mentioned") ( Schmidt, 2004b).
} 
occupied, on the other hand, by single or several, mostly related, persons. Water mills, in particular, are owned by a number of people. Such cases are the result of the locally-practised inheritance system, which will be discussed later in this chapter. Generally, land in Shigar is relatively equally divided between households. Apart from the former cho and some wazir families ${ }^{14}$, there are no big land owners, and only a few households have no land of their own (Polzer and Schmidt, 2000). In most cases, land is cultivated by the land proprietors themselves, but occasionally it is leased out to tenants. Today, three types of lease can be distinguished in Shigar:

a) The permanent or occupancy tenancy (mustaqil kashtkari) is based on the right of permanent possession, which is inheritable. Such lease contracts are mentioned in the revenue records and are found today only on land which is owned by the cho or by wazir families. Advantageous for the tenant is the fact that the land owner would find it very hard to increase the rent or cancel the contract.

b) Most leases are today based on oral contracts between land owners and tenants. Referring to the annual basis of the lease one speaks of temporary tenants or tenants-at-will (ghair mustaqil kashtkar). As rent, a specific amount of grain is fixed in spring and has to be paid by the tenant to the land owner in autumn, independent of the yield and of the actual crops grown on the field.

c) A traditional, but today only very rarely practised, lease form is the so-called bartap system. Such leases are also arranged orally but differ in the form of rent: the harvested grain is divided equally between landowner and tenant, thus being dependent on the yield. In this sharecropping system, the advantages for tenants in case of a bad harvest are obvious, while the disadvantage for land owners can be seen in the lack of planning reliability.

In general, the relationship between the land owner and the tenant goes further than the pure contract of lease. Tenants not infrequently carry out field or other work for the land-owner without any payment, if the latter asks them. On the other hand, land owners often feel responsibility for their tenants and help them if they are in need of money, food or medicine.

Although most of the settled areas in and around villages are in the possession of individuals and are subject to these individuals' own decisions, ${ }^{15}$ there are local customs and rules which restrict the use to which a land proprietor may put the land. For example, in accordance with the ban on free grazing, livestock is kept away from the cropped land during the growing season. In most villages a watchman (lurapa), who is appointed by the village community or by a tsharma, checks that no animals enter the fields. ${ }^{16}$ The use of a farmer's own fields is also affected by the rights of way which allow everybody to cross fields after harvest. Other local rights include customs about the construction of houses on specific areas, change of land use and the planting of trees.

As land is not forever in the possession or ownership of one person, questions arise about the transfer and alienation of land. During the reign of the cho, most land was inherited and land transfers were carried out in an informal way or were subject to the mercy of the ruler, since he could permit or forbid the alienation of land. Under the maharaja of Jammu and Kashmir, at least until 1933, land alienation was strictly forbidden and land could only be transferred by way of inheritance. Since private land holdings in Shigar are small and most households depend to a high degree on the products of their agricultural land there is only a small market today, in which land is bought and sold, mortgaged or bartered. The most common way to transfer land is still by

\footnotetext{
${ }^{14}$ Descendents of former ministers (wazir) of the cho still use the title of wazir with their family names.

${ }^{15}$ Other lands within the settled areas include public pathways, sites and canals.

16 The lorapa of Ladakh and Zangskar perform a similar function: apart from keeping livestock away from the fields he tends the livestock that is kept in the valleys during the summer (Friedl, 1983:244; Jina, 1995:105; Labbal, 2000:169).
} 
inheritance from one possessor to the next. Today, the practice of inheritance is a mixture of Islamic rights and traditional customs, although the persons who consult households in distribution of an estate, namely religious leaders (mullahs) or thsarma, would always state that the form of inheritance in Shigar is governed purely by Islamic law. The governing principle of this law could be outlined as follows: property is divided equally between all children with the exception that sons inherit twice as much as daughters. ${ }^{17}$ However, the reality differs from the theoretical concept, since daughters mostly gift their share to their brothers. This practice is in contradiction of Islamic law, but is a reminder of the traditional local customs under which girls were excluded from the inheritance. Due to the significantly increased survival rate of children and, thus, of heirs over the last decades the practised form of inheritance resulted in an extremely fragmented field area: not only is the land-holding of each household reduced from generation to generation, but also the sizes of the fields themselves, as can be seen in Fig. 5.

\section{Conclusion}

In Shigar, where water and land resources are very limited, land use is directed mainly at sustaining the livelihoods of the local population. The mixed mountain agriculture practised here is a reflection of dynamic utilisation strategies developed for different ecological niches. It cannot, however, be explained simply as an adaptation to the natural environment, since decisions about land use are also influenced by political and economic incidents, as well as inheritance patterns. Arable farming and animal husbandry are in a reciprocal relationship, where each complements and is dependent on the other. Raising a whole range of agricultural plants and types of livestock can be seen as a strategy to minimise risks. Regarding the administration of land, today we find local indigenous institutions co-existing with governmental administration and rules. Important autochthonous institutions, such as the tsharma, lurapa and hrkongstrung, fulfil tasks and functions at a local level that are not covered by the governmental administration. Ownership and usufruct rights over land vary between different land resources. The vast majority of land, including high mountain regions, glaciers and waste land, is owned by the state, but since utilisation is not restricted such lands can be defined as open-access resources. Pastures are, in most cases, commons or common property resources with usufruct rights limited by the inclusion and exclusion of specific user groups. Individual ownership of land is only realised for the irrigated agricultural fields, fruit and vegetable gardens and meadows, and the utilisation of such land is legally the responsibility of the land owner. However, the utilisation of privately held land is also regulated by local customs, such that individual strategies of land management are influenced by communal decisions.

To sum up, land resources in Baltistan are managed by a well-defined group of interdependent resource users who are working within a given set of rules and regulations. Local institutions governing land use have been shown to be relatively robust and flexible. The good condition of the cultivated land, as well as the fact that there are no signs of serious degradation or over-utilization of pastures in Shigar, show that the management of land is carried out by the village communities in a relatively effective and sustainable way. In order to achieve the goals of the Global Mountain Summit, hold in Bishkek in 2002, namely "to improve the livelihoods of mountain people, to protect mountain ecosystems and to use mountain resources more wisely", it seems obvious that local communities must be empowered and the principles of subsidiarity should be respected.

\footnotetext{
${ }^{17}$ For further and more detailed information on the title of inheritance in Shigar see Lentz (2000); Schmidt (2004b).
} 

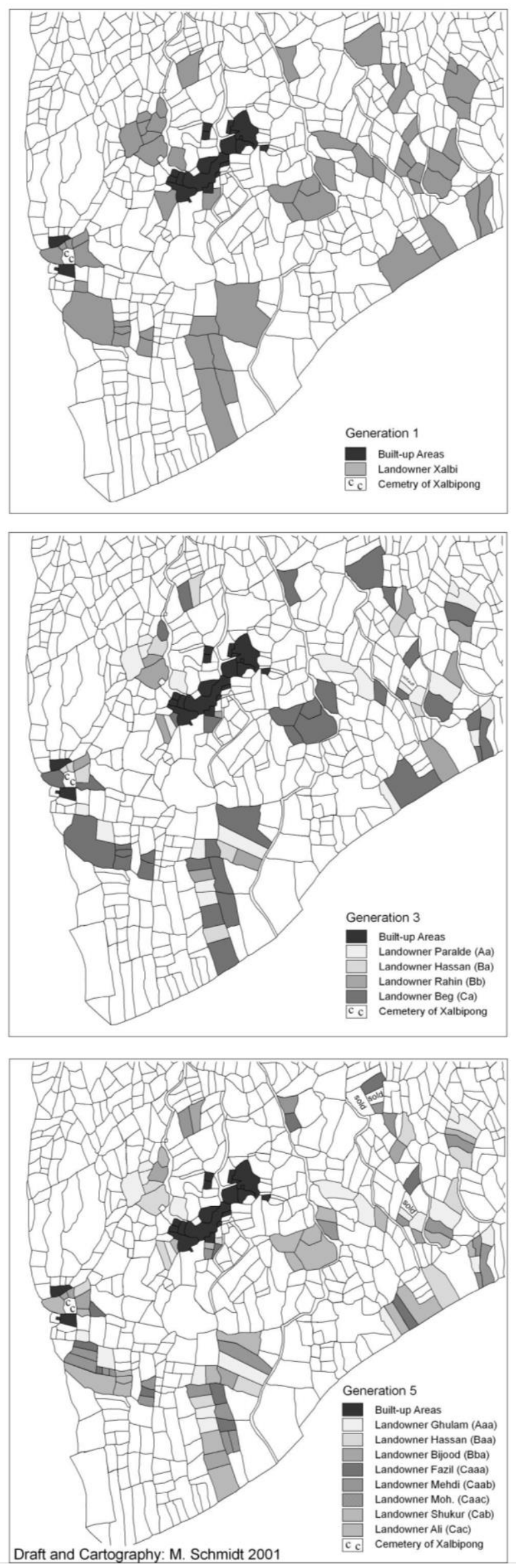

Figure 5. Land property of Xalbipong clan in Shigar. 


\section{References}

Afridi, Banat Gul. 1988. Baltistan in History. Peshawar: Emjay Books International.

Baker, J. Mark. 1997. "Common Property Resource Theory and the kuhl Irrigation Systems of Himachal Pradesh, India." Human Organization 56, 2:199-208.

Berkes, Fikret (Ed.). 1989. Common Property Resources: Ecology and Community-based Sustainable Development. London: Belhaven Press.

Berkes, Fikret, Davidson-Hunt, Iain, and Kerril Davidson-Hunt. 1998. "Diversity of Common Property Resource Use and Diversity of Social Interests in the Western Indian Himalaya." Mountain Research and Development $18,1: 19-33$.

Cunningham, Alexander. 1854. Ladák: Physical, Statistical, and Historical; with Notices of the Surrounding Countries. London. (Reprint: New Delhi: Sagar Publications 1977).

Dainelli, Giotto. 1924. Spedizione Italiana de Filippi nell Himàlaia, Caracorùm e Turchestàn Cinese (1913-14). Serie II - Resultati geologici e geografici. Vol. 8, Le condizioni delle genti. Bologna: Zanichelli.

Ehlers, Eckart, and Hermann Kreutzmann (Eds.). 2000. High Mountain Pastoralism in Northern Pakistan. Stuttgart: Franz Steiner. (= Erdkundliches Wissen 132).

Emerson, Richard. 1984. "Charismatic Kingship: a Study of State-Formation and Authority in Baltistan." Journal of Central Asia 7, 2:95-133.

Feeny, David, Berkes, Fikret, McCay, Bonnie J., and James M. Acheson. 1990. "The Tragedy of the Commons: Twenty-two Years Later." Human Ecology 18, 1:1-19.

Friedl, Wolfgang. 1983. "Landwirtschaft, Viehzucht und Handwerk in Zangla.“ In Recent research on Ladakh: history, culture, sociology, ecology. Proceedings of a Conference Held at the University Konstanz, 1981 November 23-26. pp. 237-252. Ed Detlef Kantowsky and Reinhard Sander. München: Weltforum (= Schriftenreihe Internationales Asienforum 1).

Government of Pakistan. 1972. Population Census of Northern Areas 1972. District Census Report Baltistan. Census Organisation. Ministry of Interior. States and Frontier Regions. Islamabad.

Government of Pakistan. 1984. 1981 District Census Report of Baltistan. Population Census Organisation. Statistics Division. Islamabad.

Government of Pakistan. 2000. 1998 District Census Report of Baltistan. Population Census Organisation. Statistics Division. Islamabad.

Grist, Nicky. 1985. "Ladakh, a Trading State." In Ladakh: Himalaya Occidentale:Ethnologie, Écologie: Recent Research No.2. Ed Claude Dendaletche. Pau: Centre Pyrénéen de Biologie et Anthropologie des Montagnes (= Acta Biologica Montana 5).

Hardin, Garrett. 1968. "The Tragedy of the Commons." Science 162:1243-1248.

Hashmatullah Khan, Al-Haj Maulvi. 1987. History of Baltistan. Islamabad: National institute for Folk and Traditional Heritage (Lok Virsa).

Hewitt, Farida. 1991. Women in the Landscape: a Karakoram Village before „Development“. Ph.D. Dissertation, University of Waterloo.

Imperial Gazetteer of India. 1908. Kashmir and Jammu. Provincial Series, 16. Oxford. (Reprint: Lahore: Sang-eMeel Publications, 1983).

Jina, Prem Singh. 1995. HighPpasturelands of Ladakh Himalaya. New Delhi: Indus Publishers Co.

Knight, Edward Frederic. 1893. Where Three Empires Meet: A Narrative of Recent Travel in Kashmir, Western Tibet, Gilgit, and the Adjoining Countries. London. (Reprint: Lahore: Sang-e-Meel Publications 1996).

Kreutzmann, Hermann. 1993. "Challenge and Response in the Karakoram: Socioeconomic Transformation in Hunza, Northern Areas, Pakistan." Mountain Research and Development 13, 1:19-39.

Labbal, Valerie. 2000. "Traditional Oases of Ladakh: A Case Study of Equity in Water Management.” In Sharing Water: Irrigation and Water Management in the Hindukush - Karakoram - Himalaya, pp. 163-183. Ed Hermann Kreutzmann. Oxford: Oxford University Press: 163-183.

Lawrence, Walter R. 1895. The Valley of Kashmir. London: H. Frowde. (Reprint: Srinagar: Kesar Publishers 1967). 
Lentz, Sabine. 2000. Rechtspluralismus in den Northern Areas / Pakistan. Cologne: Rüdiger Köppe. (= Culture Area Karakorum Scientific Studies 9).

MacDonald, Kenneth I. 1994. The Mediation of Risk: Ecology, Society and Authority in Askole, a Karakoram Mountain Agro-pastoral Community. Ph.D. Dissertation, University of Waterloo.

Malik, M. Bashir 1961. Census of Northern Areas, 1961. Agency Census Report. Baltistan Agency. Parts I-V. Vol.6.

Mann, Rann Singh. 1986. The Ladakhi: A Study in Ethnography and Change. Calcutta: Anthropological Survey of India.

Osmaston, Henry, Fisher, Rod, Frazer, Janet, and Tony Wilkinson. 1994. "Animal Husbandry in Zangskar." In Himalayan Buddhist Villages: Environment, Resources, Society and Religious Life in Zangskar, Ladakh, pp. 199-248. Ed John Crook and Henry Osmaston. Bristol: University of Bristol.

Ostrom, Elinor. 1990. Governing the Commons: the Evolution of Institutions for Collective Action. Cambridge: Cambridge University Press.

Ostrom E.; Dietz, T.; Dolsak, N.; Stern, P. C.; Stonich, S. a. E. U. Weber (Eds.). 2002. The Drama of the Commons. Washington: National Academy Press.

Petech, Luciano. 1977. The Kingdom of Ladakh, c. 950-1842. Roma: Institituto Italiano per il Medio ed Estremo Oriente. Serie Orientale Roma 51.

Polzer, Claudia, and Matthias Schmidt. 1999. "The Transformation of Political Structure in Shigar Valley / Baltistan." In Mountain Societies in Transition: Contributions to the Cultural Geography of the Karakorum, pp. 179-210. Ed Andreas Dittmann. Cologne: Rüdiger Köppe. (= Culture Area Karakorum Scientific Studies $6)$.

Rhoades, Robert E., and Stephen I. Thompson. 1975. "Adaptive Strategies in Alpine Environments: beyond Ecological Particularism." American Ethnologist 2, 3:535-551.

Rizvi, Janet. 1999. "A Self-reliant Economy: the Role of Trade in Pre-independence Ladakh." Ladakh Studies 12:31-35.

Robertson, George Scott. 1896. The Káfirs of the Hindu-Kush. London: Lawrence \& Bullen.

Schmidt, Matthias. 2000. "Pastoral System in Shigar / Baltistan: Communal Herding Management and Pasturage Rights." Pp. 121-150 in High Mountain Pastoralism in Northern Pakistan edited by Eckart Ehlers and Hermann Kreutzmann. Stuttgart: Franz Steiner. (= Erdkundliches Wissen 132).

Schmidt, Matthias. 2004a. "Interdependencies and Reciprocity of Private and Common Property Resources in the Central Karakorum." Erdkunde 58, 4: 316-330.

Schmidt, Matthias. 2004b. Boden- und Wasserrecht in Shigar, Baltistan: Autochthone Institutionen der Ressourcennutzung im Zentralen Karakorum. Sankt Augustin: Asgard. (= Bonner Geographische Abhandlungen 112).

Schuler, Sidney. 1978. "The „Story of the Creation of Shigar“ of Wazir Ahmad." Central Asiatic Journal 22:102-120.

Sheikh, Abdul Ghani. 1998. "Ladakh and Baltistan through the Ages." In Karakorum - Hindukush - Himalaya: Dynamics of Change II , pp. 337-349. Ed Irmtraud Stellrecht. Cologne: Rüdiger Köppe. (= Culture Area Karakorum Scientific Studies 4/II).

Singh, Katar. 1994. Managing Common Pool Resources: Principles and Case Studies. Delhi: Oxford University Press.

Singh, Thakar. 1914. Assessment Report of the Skardo Tahsil of the Ladakh District. Lahore.

Thorp, Robert. 1870. Cashmere Misgovernment: An Account of the Economic and Political Oppression of the People of Kashmir by the Maharaja's Government. London.

Vigne, Godfrey T. 1842. Travels in Kashmir, Ladak, Iskardo, the Countries Adjoining the Mountain-Course of the Indus, and the Himalaya, North of the Panjab. (2 Vols.) London: H. Colburn. (Reprint: Karachi: Indus Publications 1987).

Younghusband, Francis E. 1909. Kashmir. London: A. \& C. Black. 
Matthias Schmidt (b. 1968) studied Geography at the University of Bonn. He is specialized in human geography and political ecology of mountain areas of South and Central Asia, and did his Ph.D. on water and property rights in Baltistan. Since 2005 he is research assistant at the Department of Geography at the Freie Universität Berlin. 